\title{
PREPARATION AND PROPERTIES OF THICK FILM RESISTORS CONTAINING CADMIUM GLASSES AND CADMIUM OXIDE
}

\author{
R. KUŽ̀EL and J. BROUKAL \\ Faculty of Mathematics and Physics, Charles University, Ke Karlovu 5, 12116 Prague 2 and State \\ Glass Research Institute, 50192 Hradec Králové I, Czechoslovakia
}

(Received June 11, 1979)

\begin{abstract}
The electrical properties of resistors comprising finely divided $\mathrm{CdO}$ and cadmium glass, were investigated. The change in a temperature coefficient of resistance from about $-500 \mathrm{ppm} /{ }^{\circ} \mathrm{C}$ to $+70 \mathrm{ppm} /{ }^{\circ} \mathrm{C}$ was realized by addition of a further component to the resistor paste. Differential thermal analysis, X-ray diffraction analysis and scanning electron microscopy were used for studying crystalline phases in glass containing CdO.
\end{abstract}

\section{INTRODUCTION}

Thick film resistors are usually produced by using noble metals. We have tried to prepare the resistors either without or with only small percentages of noble materials. In accordance with a model of a conductance mechanism in a ceramic type of resistor, we have proposed using a strongly degenerated semiconductor, cadmium oxide, as the conductive material. ${ }^{1}$ The problem of finding suitable glasses was solved by using cadmium glasses.

\section{ELECTRICAL PROPERTIES OF RESISTORS}

\subsection{Preparation of Thick Film Resistors}

Compositions used for the preparation of resistors contained, as a solid ingredient, a mixture consisting essentially of $50 \%$ to $100 \%$ by weight of finely divided cadmium glass frit, 0 to $50 \%$ CdO powder, 0 to $6 \%$ further additions and also a liquid vehicle. The glasses from the system $\mathrm{Na}_{2} \mathrm{O}-\mathrm{BaO}-\mathrm{CdO}-$ $\mathrm{PbO}-\mathrm{B}_{2} \mathrm{O}_{3}{ }^{2}$ were selected. The glasses used were melted in an electrical furnace in platinum-rhodium crusibles at the temperature of $1300^{\circ} \mathrm{C}$. Molten glasses were fritted into distilled water. Glass frit was ground in an agate planet mill into grain sizes smaller than $5 \mu \mathrm{m}$. The glasses marked EV 6 , and EV 12 contain $\mathrm{CdO}$ amounting to 26 mole $\%$ and 35 mole \%, respectively. The EV 21 glass differs from EV 12 glass, especially in zero content of $\mathrm{Na}_{2} \mathrm{O}$. The resistor compositions were applied by a stencil screen printing method onto alumina substrates which were then fired in a furnace with a suitable temperature schedule at peak temperatures ranging from $600^{\circ} \mathrm{C}$ to $760^{\circ} \mathrm{C}$.

\subsection{Resistivity of Resistors}

An interesting dependence of resistivity of resistors on temperature was observed in a firing cycle, showing a structure at temperatures of $300^{\circ} \mathrm{C}$, $440^{\circ} \mathrm{C}, 530^{\circ} \mathrm{C}$ and a flat maximum at $700^{\circ} \mathrm{C}$ when heated (Figure 1). The observed peaks are assumed

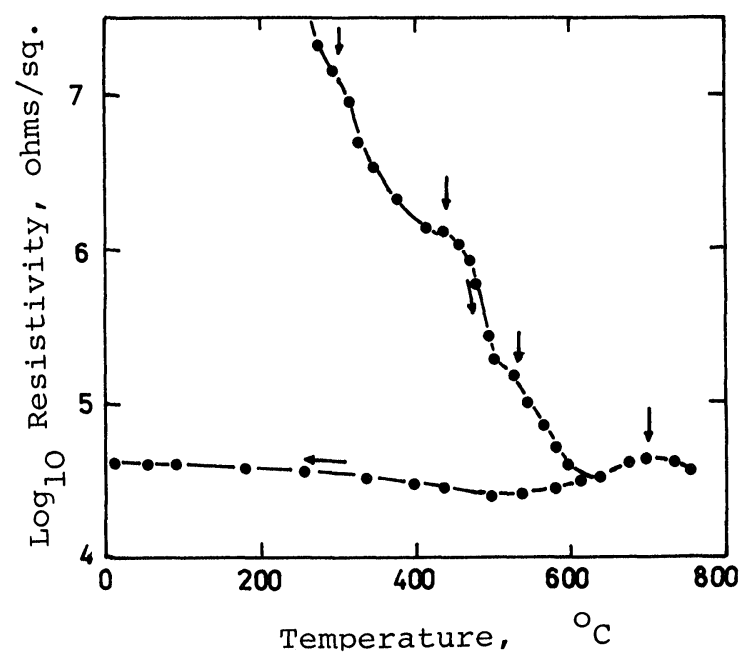

FIGURE 1 Sheet resistivity as a function of temperature in a firing cycle. ( $80 \mathrm{wt} . \% \mathrm{EV} 6$ glass $+20 \mathrm{wt} . \% \mathrm{CdO}$ ). 
to be associated with a presence of further crystalline phases (except $\mathrm{CdO}$ ) in the layer as the following analyses demonstrated.

Measurements of resistance changes taken at the temperature of $120^{\circ} \mathrm{C}$ after 1000 hours showed only a slight variation $(-0.2 \%)$ in resistor resistance between firing temperatures of $680^{\circ}$ and $760^{\circ} \mathrm{C}$, as shown by curve 1 in Figure 2 .

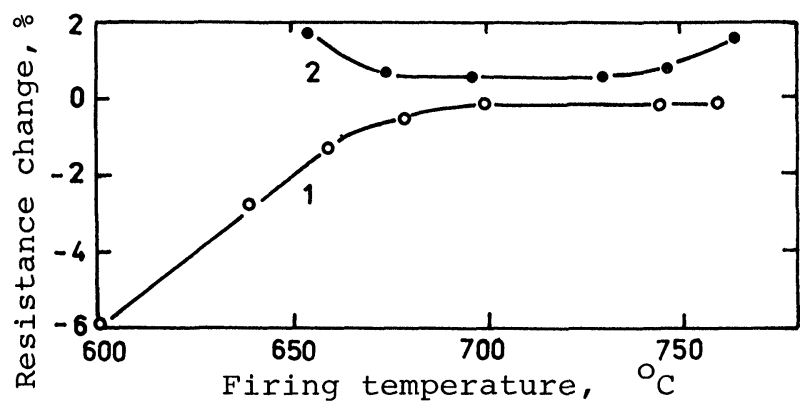

FIGURE 2 Resistance change at $120^{\circ} \mathrm{C}$ after 1000 hours. Curve $1-80 \%$ EV 6 glass $+20 \%$ CdO; curve $2-80 \%$ EV 12 glass $+15.4 \% \mathrm{CdO}+4.6 \% \mathrm{Bi}_{2} \mathrm{Ru}_{2} \mathrm{O}_{7}$.

The resistivity vs. firing temperature plot exhibits an outstanding maximum at $700^{\circ} \mathrm{C}$ for resistors containing a high percentage of EV 6 glass (about $80 \%$ or more) as shown in Figure 3. For resistors containing a smaller amount of EV 6 glass (about $70 \%$ ) (curve 2) or containing EV 12 glass as well as EV 21 glass, the maximum does not appear; the resistivity having a much lower dependence on peak firing temperature, especially in the range from $690^{\circ} \mathrm{C}$ to $760^{\circ} \mathrm{C}$.

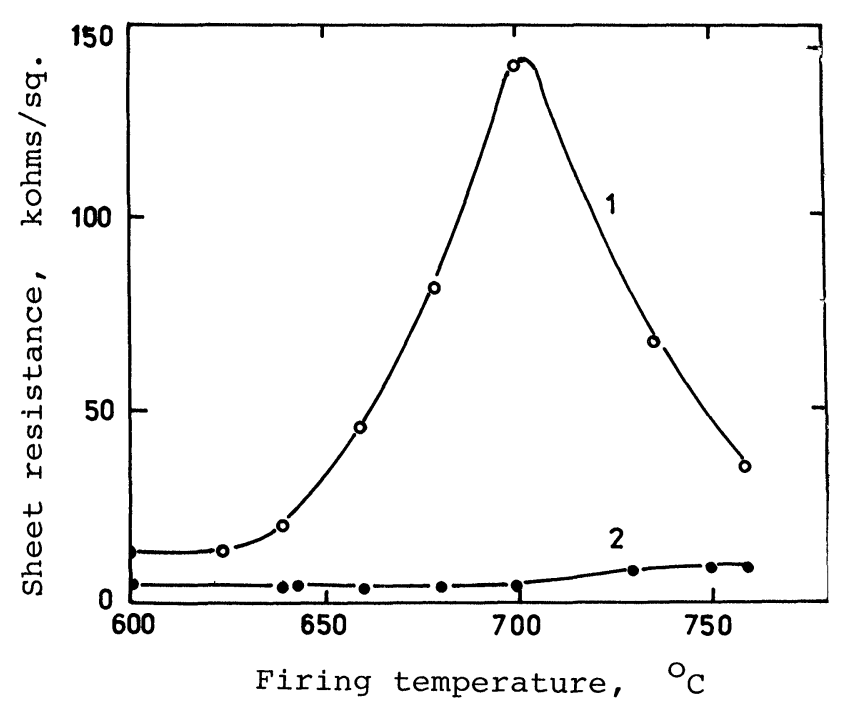

FIGURE 3 Sheet resistance as a function of firing temperature (1) $-80 \% \mathrm{EV} 6+20 \% \mathrm{CdO}$; (2) - 70\% EV 6 $+30 \% \mathrm{CdO}$.

By using various kinds of glasses and a suitable peak firing temperature ( $8 \mathrm{~min}$ at peak), it is possible to change the resistivity from about $1 \mathrm{kohm} / \mathrm{sq}$. to $1 \mathrm{Mohm} / \mathrm{sq}$. using resistors of about $10 \mu \mathrm{m}$ thickness. The resistors containing under $60 \%$ glass are not usually available owing to their lower stability.

\subsection{Temperature Coefficient of Resistance}

The temperature dependence of resistivity below $200^{\circ} \mathrm{C}$ is linear (Figure 1) with a constant temperature coefficient of resistance (TCR) of about
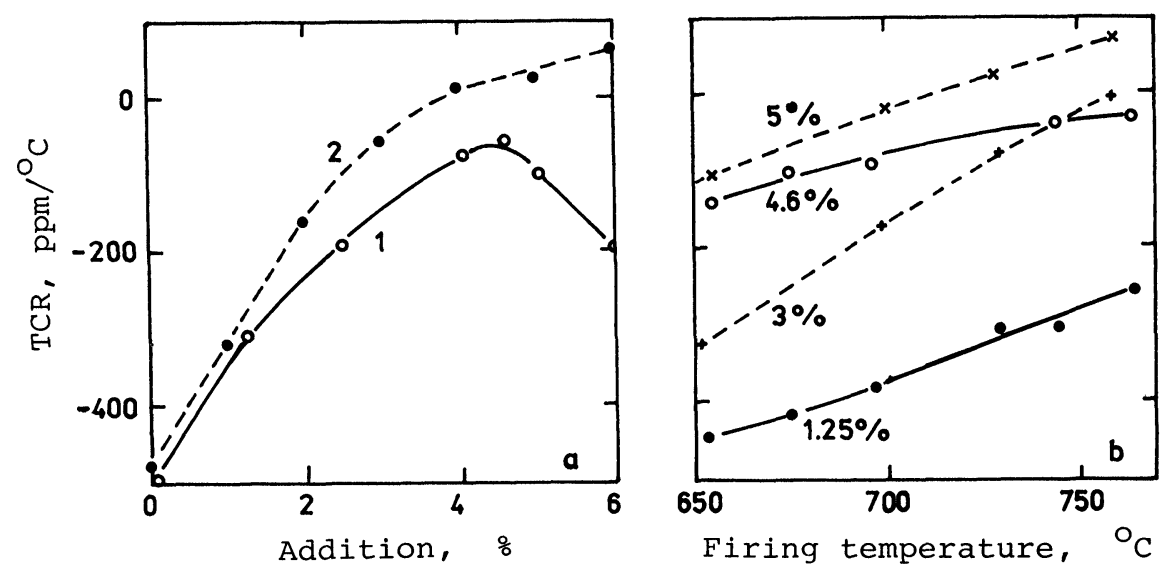

FIGURE 4 Dependence of TCR (a) on addition of $\mathrm{Bi}_{2} \mathrm{Ru}_{2} \mathrm{O}_{7}$ or $\mathrm{Pb}_{2} \mathrm{Ru}_{2} \mathrm{O}_{6}$ (dashed lines); (b) on firing temperature. 
$-500 \mathrm{ppm} /{ }^{\circ} \mathrm{C}$, disregarding the kind of glass. This value was reduced by adding further compounds to the resistor composition.

The addition of $\mathrm{CdCl}_{2}$ reduced the TCR only to $-200 \mathrm{ppm} /{ }^{\circ} \mathrm{C}$. Better results were achieved by the addition of $\mathrm{Bi}_{2} \mathrm{Ru}_{2} \mathrm{O}_{7}$. Figure $4 \mathrm{a}$ (curve 1) shows a strong change in the TCR of resistors fired at $730^{\circ} \mathrm{C}$ with variations in the amount of the above mentioned compound. The resistor composition contained $80 \%$ by weight of EV 12 glass and $20 \%$ by weight of a powder mixture of solid $\mathrm{CdO}$ and $\mathrm{Bi}_{2} \mathrm{Ru}_{2} \mathrm{O}_{7}$. The minimum of the TCR (about $-50 \mathrm{ppm} /{ }^{\circ} \mathrm{C}$ ) was reached at $4.6 \%$ by weight of the compound. These resistors are sufficiently stable at $120^{\circ} \mathrm{C}$ as shown by curve 2 in Figure 2.

The TCR can be controlled very well from $-500 \mathrm{ppm} /{ }^{\circ} \mathrm{C}$ up to $+70 \mathrm{ppm} /{ }^{\circ} \mathrm{C}$ by the addition of $\mathrm{Pb}_{2} \mathrm{Ru}_{2} \mathrm{O}_{6}$ to the resistor composition comprising EV 21 glass as shown in Figure 4 (dashed lines). The zero value of the TCR was achieved at $3.8 \%$ by weight of this compound.

The further reduction in the TCR can be reached by using a higher peak firing temperature as illustrated in Figure $4 \mathrm{~b}$ for both compounds in two amounts.

\section{ANALYSIS OF SPECIAL CADMIUM GLASSES WITH CADMIUM OXIDE}

The above given results of measurements of electrical properties of thick film resistors can be explained by the formation and presence of crystalline phases in thermally treated cadmium glasses with additions as following analyses showed. The thermal treatment temperatures of samples were chosen according to the distribution of the peaks along the curve of differe ntial thermal analysis of the basic EV 6 glass as shown in Figure 5. The main D.T.A. peaks coincide well with the "peaks" observed in the temperature dependence of resistivity presented in Figure 1. Specimens were investigated for crystallinity using an X-ray powder diffraction technique. The ascertained crystalline phases are listed in Table $I$. Crystalline phases marked "A", " $B$ " and "C" have not been identified yet.

The values $d$ of the most intensive X-ray diffraction interplanar spacings are shown in Table II.

Scanning electron micrographs of the thick film cadmium resistors are shown in Figure 6.

The influence of the temperature treatment on the formation or destruction/dissolving of the crystalline phases is evident from Figure 6.

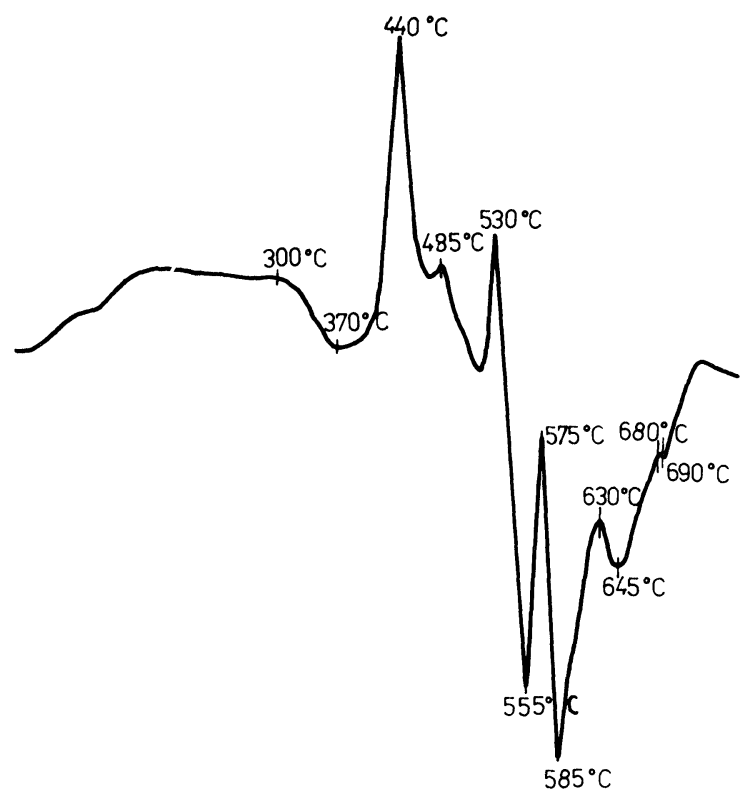

FIGURE 5 Differential thermal analysis of EV 6 glass.

TABLE I

Crystalline phases in the thermally treated EV 6 glass and in the mixture of EV 6 glass with $\mathrm{CdO}$ addition.

\begin{tabular}{|c|c|c|}
\hline Sample & $\begin{array}{l}\text { Treatment } \\
\text { temperature } \\
{ }^{\circ} \mathrm{C}\end{array}$ & Crystalline phases \\
\hline $\begin{array}{l}100 \text { wt. } \% \\
\text { EV } 6 \text { glass }\end{array}$ & $\begin{array}{l}450 \\
485 \\
530 \\
570 \\
605 \\
630 \\
700 \\
730\end{array}$ & 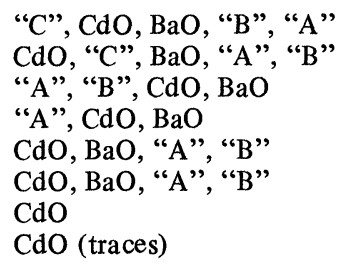 \\
\hline $\begin{array}{l}80 \text { wt. } \% \\
\text { EV } 6 \text { glass }+ \\
20 \text { wt. } \% \text { CdO }\end{array}$ & $\begin{array}{l}450 \\
485 \\
530 \\
570 \\
605 \\
630 \\
700 \\
730\end{array}$ & 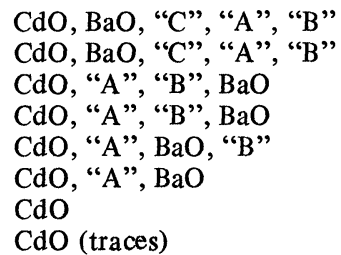 \\
\hline
\end{tabular}

\section{CONCLUSION}

From the analysis and measurement results we can assume that the stability of thick film resistors was essentially effected by the formation and presence of other crystalline phases except $\mathrm{CdO}$. The 
TABLE II

X-ray diffraction interplanar spacing of crystalline phases " $A$ ", “B”, "C". $\left(d, 10^{-10} \mathrm{~m}\right)$

\begin{tabular}{|c|c|c|c|c|c|}
\hline \multicolumn{2}{|c|}{ "A" } & \multicolumn{2}{|c|}{ "B" } & \multicolumn{2}{|c|}{ "C" } \\
\hline$I / I_{0}$ & $d$ & $I / I_{0}$ & $d$ & $I / I_{0}$ & $d$ \\
\hline 10 & 4.54 & 10 & 3.81 & 10 & 3.69 \\
\hline 6 & 4.08 & 7 & 2.68 & 8 & 2.97 \\
\hline 6 & 2.04 & 7 & 2.20 & 8 & 2.51 \\
\hline 4 & 2.84 & 6 & 3.29 & 7 & 5.00 \\
\hline
\end{tabular}
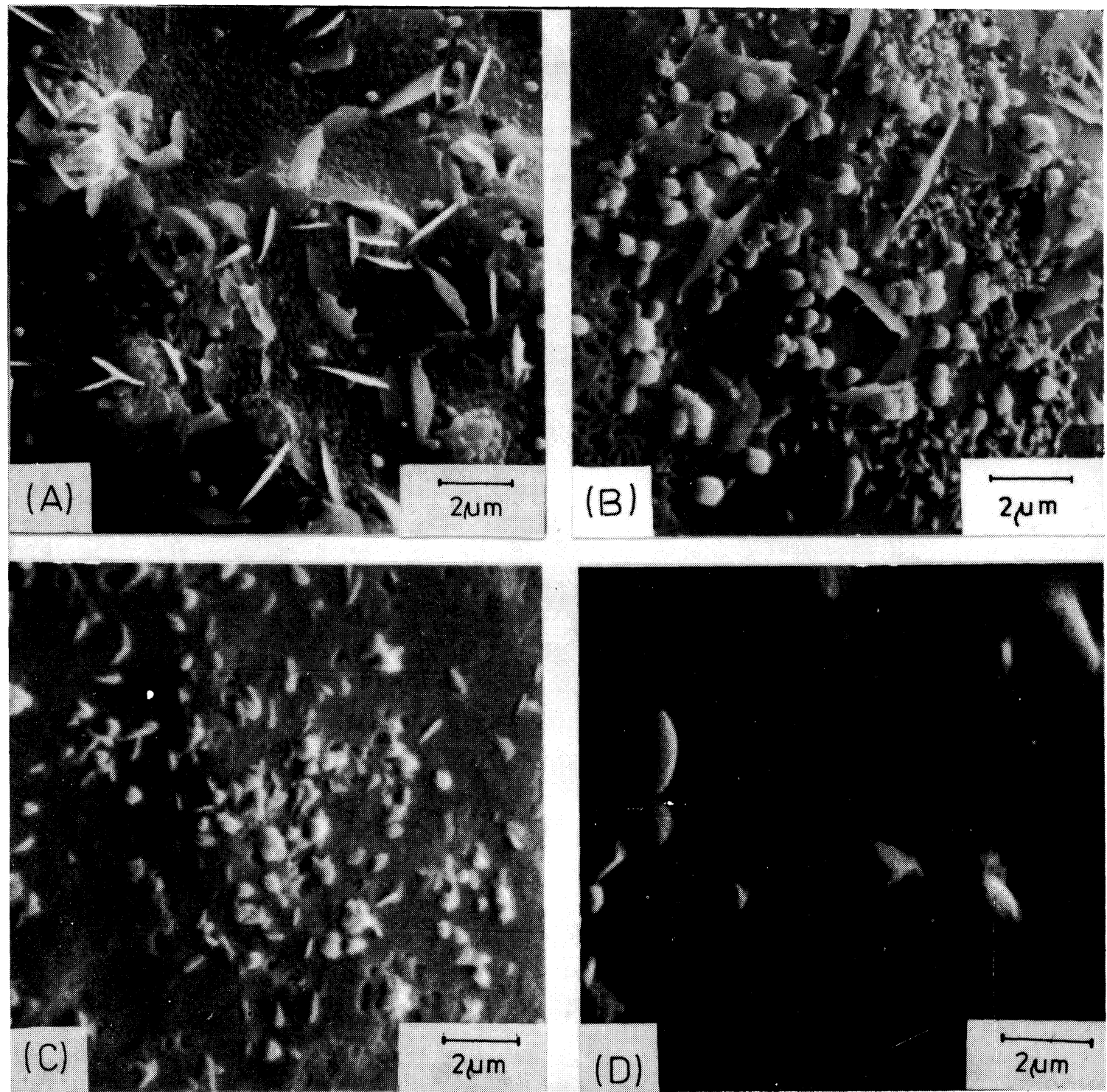

FIGURE 6 Scanning electron micrographs of the surface of EV 6 cadmium glass $(80 \mathrm{wt} . \%)$ and CdO (20 wt.\%). Annealed for $15 \mathrm{~min}$ : A at $530^{\circ} \mathrm{C}, \mathrm{B}$ at $570^{\circ} \mathrm{C}, \mathrm{C}$ at $630^{\circ} \mathrm{C}$ and $\mathrm{D}$ at $700^{\circ} \mathrm{C}$. 
examinations carried out proved that the most stabilized resistor films could be obtained from a mixture of cadmium glasses and $\mathrm{CdO}$ by a proper thermal treatment of the films at the temperatures of $700^{\circ} \mathrm{C}$ to $730^{\circ} \mathrm{C}$, at which, in most cases, only a fine crystalline $\mathrm{CdO}$ phase was determined. All other crystalline phases, such as $\mathrm{BaO}$, " $\mathrm{A}$ ", " $\mathrm{B}$ ", "C", were found to influence unfavourably the electric stability of thick film resistors which were prepared.

The analyses of the cadmium glasses with addition of $\mathrm{CdO}$ and ruthenium compounds will be published in future.

\section{REFERENCES}

1. R. KuŽel, and P. Höschl, Tiß̌̌téné odporové vrstvy, in: L Pátý (ed.), Sborník referátů o spolupráci matematickofyzikální fakulty s praxí, Universita Karlova, Praha (1976) 76-83 (in Czech).

2. Masaki Aoki, Mitsuo Wada and Mitsuhiro Ohtani, Glass for cadmium oxide glaze resistor, Japan. Kokai 74, 32,907 (March 26, 1974). 

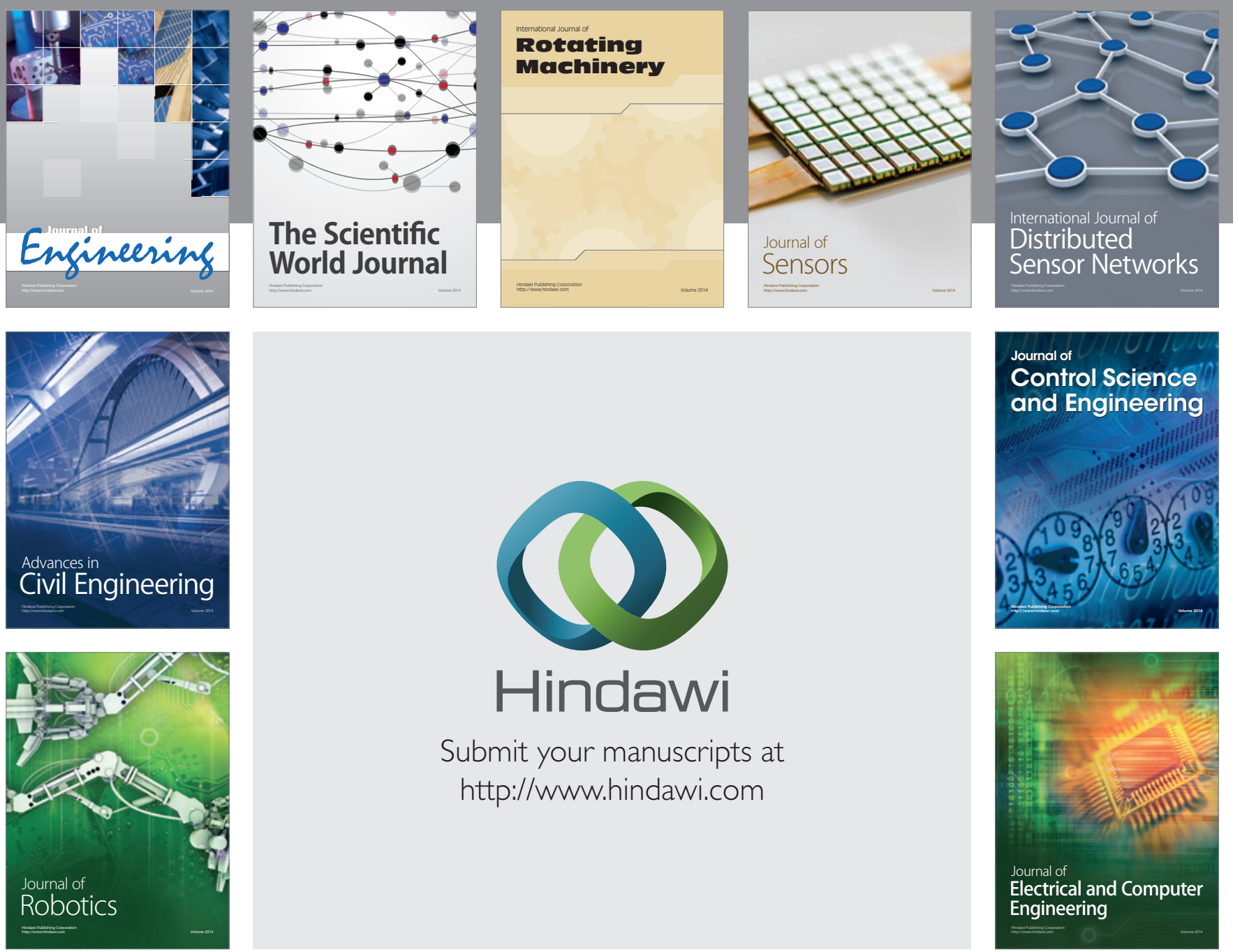

Submit your manuscripts at

http://www.hindawi.com
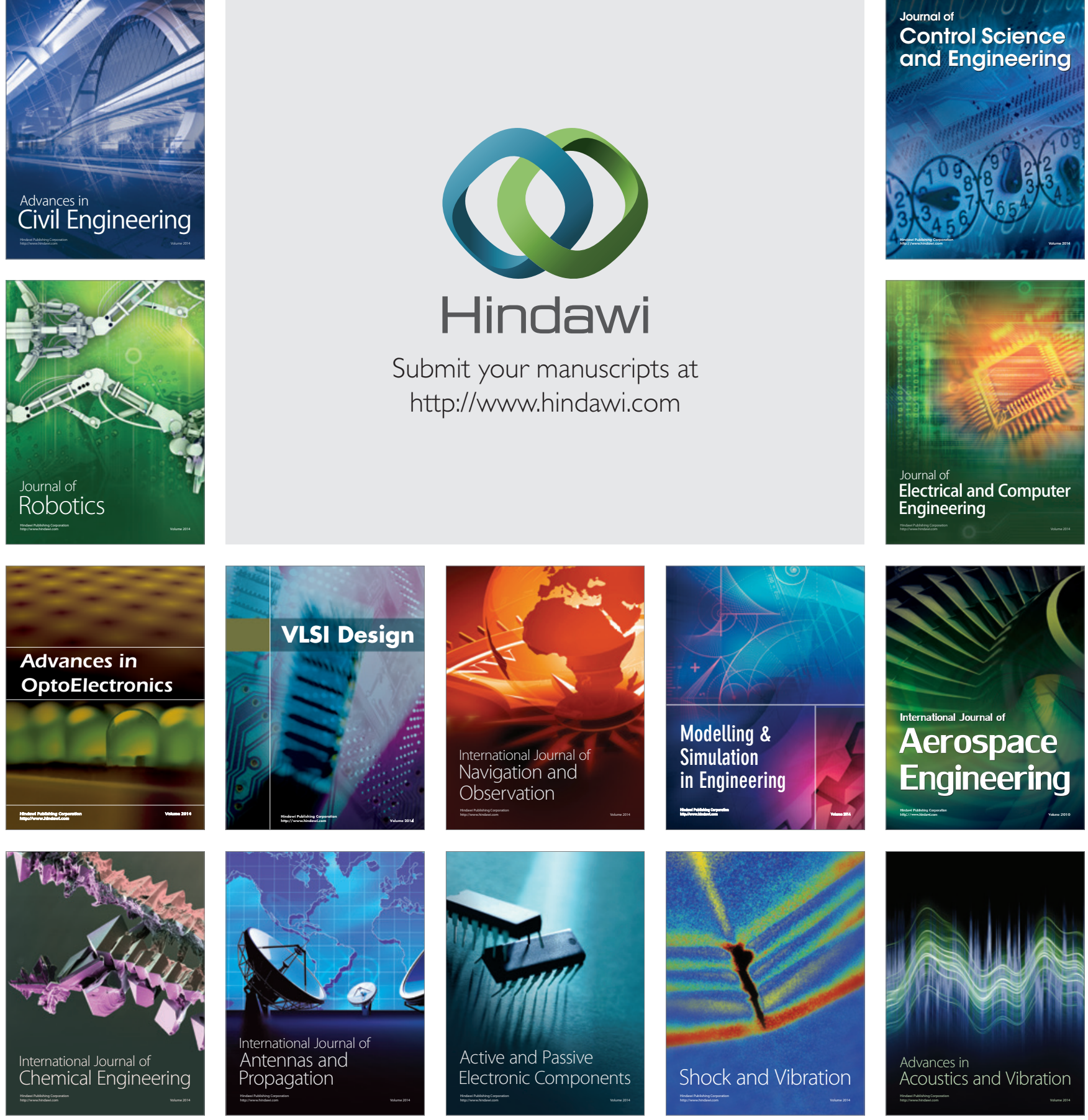